UDC 636.2:57.047(497.113)"2005/2016"

637.12(497.113)"2005/2016"

COBISS.SR-ID 253139980

Original research paper

Acta Agriculturae Serbica, Vol. XXII, 44 (2017); 133-145

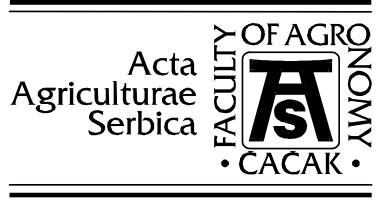

\title{
Thermal comfort of cows and temperature- humiduty index in period of 2005-2016 in Vojvodina region (Serbia)
}

\author{
Marko R. Cincovicí ${ }^{1}$, Mira Majkić ${ }^{1}$, Branislava Belić ${ }^{1}$, Nada Plavša ${ }^{1}$, \\ Ivana Lakić ${ }^{1}$, Miodrag Radinović ${ }^{1}$ \\ ${ }^{1}$ University of Novi Sad, Faculty of Agriculture, Department of Veterinary \\ Medicine, Laboratory of Pathophysiology, Novi Sad, Serbia \\ Corresponding author: mcincovic@gmail.com
}

\begin{abstract}
The aim of this study is to determine value of temperature-humidity index (THI) in period of 2005-2016. in Vojvodina and their correlations with milk production and temperature of body surface of animals. THI index is calculated according to the following formula $T H I=(1,8 \times$ Temperature $)-(1$-Relative Humidity $) \times$ (Temperature14,3)+32. Temperature and humidity data were collected directly from Hydrometeorological Institute of Serbia. Average THI values were calculated for every month for every year from 2005 to 2016 . Measuring spots were cities Vršac, Zrenjanin, Kikinda, Palić, Sombor, Rimski Šančevi and Sremska Mitrovica. Temperature and humidity are noted at $14^{\mathrm{h}}$, so they represented maximal average values of THI index. Trend of THI values was represented for each day in every month in years from 2005. to 2016. Average production of drinking milk for year of 2016 was calculated. This year was chosen because is the last year of research and represents cumulative effect of heat stress in cows. Data were collected from Statistic Institute of R. Serbia. Thermo-vision camera was used for determining skin temperature of udder and skin in eye region. Results were showed that temperature ranged from 40.3 in January to 77.5 in July. Average maximal THI value in period of 2005-2016 showed that heat stress was presented in May, June, July and August. Drinking milk production was the greatest in January. After that it started dropping. The lowest production of drinking milk was noted in August with an increase afterwards till December. Body surface temperature was ranged from 34.1 to $38.5^{\circ} \mathrm{C}$. The highest body temperature was measured at August and the lowest in winter
\end{abstract}


time. Significant negative correlation between ten-year average THI value and milk production was noted. Positive correlation was noted between THI and body temperature. From 2005 to 2016 positive linear trend of THI values that were measured in hottest period of day was noted. In every month statistically significant linear trend of rising THI value was founded, except in January, October and November. Extremely hot summers in Serbia appear in every five years when cows are affected the most. Showed data indicated global warming and climate changes which affect biological adaptation of cows.

Key word: THI, heat stress, cow, trend.

\section{Introduction}

Extreme weather can affect both productivity and animal welfare. Dairy cows are particularly susceptible to heat-stress which is caused by high temperature and humidity. Because of that, integrative measures have been developed in order to evaluate microclimates of animals, especially in hot weather (Dunn et al., 2014). Hahn et al. (2003) presented a comprehensive review of the assessment of thermal factors on livestock. These factors included local meteorological measures of the air temperature, humidity, wind speed, mean radiant temperature and solar radiation. These factors should be considered with data of physiological state of organism in given moment and given conditions. Animals are the most productive and efficient in thermo neutral zone. All changes that are out of this zone (above the upper or the lower critical temperature) can lead to stress and reduction in animal production (Gaughan et al., 2002).

A common measure of heat-stress is THI which is developed initially for humans and it is extended for dairy cattle. THI combines air temperature and relative humidity: lower temperatures followed with high humidity give similar stress reaction like a higher temperatures followed with lower humidity. Mader et al. (2006) added wind speed and solar radiation to THI in order to improve its effectiveness as a proxy for heat-stress in dairy cattle. They found that for each increase of $1 \mathrm{~m} / \mathrm{s}$ in wind speed THI can be reduced for 1.99 units. Also, decrease of $100 \mathrm{Wm}$ in solar radiation cause THI to drop for 0.68 units. Formula for THI is: $\mathrm{THI}=(1.8 \mathrm{~T}+32)-(0.55-0.0055 \mathrm{RH}) \times(\mathrm{T}-26.8)$; where $\mathrm{T}$ is the temperature in ${ }^{\circ} \mathrm{C}$ and $\mathrm{RH}$ is the relative humidity in \% (Dunn et al., 20014). In accordance with THI values heat-stress can be divided into: mild (THI range 7578), medium (THI range 79-83) and severe (THI>84) (Collier et al., 2011). THI can be calculated according to formula: $\mathrm{THI}=\mathrm{tdb}+0,36 \mathrm{tdp}+41,2$, where $\mathrm{tdb}$ is the maximum measured air temperature at 14:00 o'clock and tdp is dew point temperature (Bohmanova et al., 2007).

The climate can be defined as a set of atmospheric changes that are characteristic for particular geographic area. Climate elements that can form a 
particular climate (specific for one geographic area) include: insolation, temperature and humidity, air pressure, direction and speed of wind movement, as well as the presence of precipitation. Climate in Serbia can be described as moderately continental with more or less pronounced local characteristics (RHMZS, 2017). When it comes to Vojvodina, it is located in the area of moderate continental climate that has following characteristics: autumn warmer than spring, temperature transition from winter to spring is more pronounced than the autumn-to-winter transition. Average annual temperature in period of 19611990 for areas with altitude up to $300 \mathrm{~m}$ is $10.9^{\circ} \mathrm{C}$. Areas with altitude of 300 to $500 \mathrm{~m}$ have an average annual temperature about $10.0^{\circ} \mathrm{C}$, and over $1000 \mathrm{~m}$ above sea level $6^{\circ} \mathrm{C}$. Minimum temperatures are most pronounced in January and February. In mountains temperatures were from 21 to $30.7^{\circ} \mathrm{C}$, while in the lower parts of country temperature range was from 20.6 to $35.6^{\circ} \mathrm{C}$. Highest temperatures were noted in July with values from 37.1 to $42.3^{\circ} \mathrm{C}$ - in lower parts of country and $27.6-34^{\circ} \mathrm{C}$ in mountains. August is also very warm with maximum temperatures in the range from $37.4-40.3^{\circ} \mathrm{C}$.

In the latest review paper Polsky and Von Keyserligk (2017) showed the relationship between the immediate effects of environmental heat stress and the 3 key constructs of animal welfare: the biological functioning (and health) of the animal, the affective states the animal is experiencing, and the naturalness of its life under current heat management strategies. Heat stress leads to decrease milk production, dry mater intake and estrus behavior, while increase aggression, hunger and thirst and panting.

The aim of this study is to examine the temperature-humidity index in the period from 2005 to 2016 in Vojvodina region in Serbia and its correlation with milk production and skin temperature.

\section{Materials and Methods}

Temperature-humidity index: THI index is calculated according to the following formula $T H I=(1,8 \times$ Temperature $)-(1-$ Relative Humidity $) \times$ (Temperature-14,3)+32. Temperature and humidity data were collected directly from Hydro-meteorological Institute of Serbia. Average THI values were calculated for every month for every year from 2005 to 2016. Measuring spots were cities Vršac, Zrenjanin, Kikinda, Palić, Sombor, Rimski Šančevi and Sremska Mitrovica. Temperature and humidity are noted at $14^{\mathrm{h}}$, so they represented maximal average values of THI index.

Milk production: Average production of drinking milk in Serbia for 2016. was determined. This year was chosen because it is the last year of our research and represents cumulative effect of heat stress in cows. Data 
were collected from Statistical Office of the Republic of Serbia (srb., Republički zavod za statistiku).

Body surface temperature: Skin temperatures at udder and eye region were determined with use of thermo-vision camera. For this purpose we used thermal camera Testo 865, produced by Testo Ltd.

Statistics: mean values of THI, milk production and body surface temperature were determined. Regression analyses and correlation examination were conducted between THI and milk production, just as between THI and temperature of skin. Regression analysis was used for determination of linear trend changes of THI values in period of 20052016. for each day (360 measurements, 12 repetitions for 30 days). Microsoft office and Statgraphic Centurion were used in analysis.

\section{Results}

Results have showed that THI vales were from 40.3 in January to 77.5 in July. Mean maximal THI value in period of 2005-2016. showed that heat stress is presented in May, June, July and August. Consume milk production in 2016 was the highest in January. After that it decreased. The lowest milk production was noted in August. After that it started to increase until December. Body surface temperature ranged from 34.1 to 38.5. Highest body temperature was noted in August and the lowest was noted in winter time. Results are presented in Table 1. Thermograph of cows in heat stress is showed on Pictures 1 and 2.

Significant negative linear correlation between ten-year mean THI value and milk production was determined. Positive correlation was determined between THI and body surface temperature (udder, eye region). Results are represented at Graphic 2.

In period of 2005-2016. positive linear trend of THI values measured in hottest time of day was noted. There was statistically significant positive linear trend of increasing THI values in every month, except in January, October and November. Regression lines, determination coefficients and regression equals are shown in Graphics 2-13. 
Table 1. Mean THI, milk production and skin temperature in cows during year

\begin{tabular}{|l|l|l|l|l|l|l|l|l|l|l|l|l|}
\hline & Jan & Feb & Mar & Apr & May & Jun & July & Aug & Sept & Oct & Nov & Dec \\
\hline $\begin{array}{l}\text { Temperature- } \\
\text { humidity } \\
\text { index (THI) }\end{array}$ & 43.2 & 50.4 & 56.8 & 64.2 & 72.7 & 75.7 & 77.5 & 76.2 & 71.6 & 61 & 53.8 & 46.2 \\
\hline $\begin{array}{l}\text { Milk } \\
\text { production }\end{array}$ & 23.8 & 21.9 & 22.4 & 19.7 & 20.3 & 19.2 & 17.6 & 16.1 & 17.1 & 18.2 & 18.1 & 21.1 \\
\hline $\begin{array}{l}\text { Udder skin } \\
\text { temperature }\end{array}$ & 34.1 & 35.1 & 35.6 & 36.2 & 37.2 & 38.2 & 38.5 & 38.2 & 37.1 & 35.1 & 34.4 & 34.5 \\
\hline
\end{tabular}

Picture 1 and 2. Thermograph of cows under heat stress

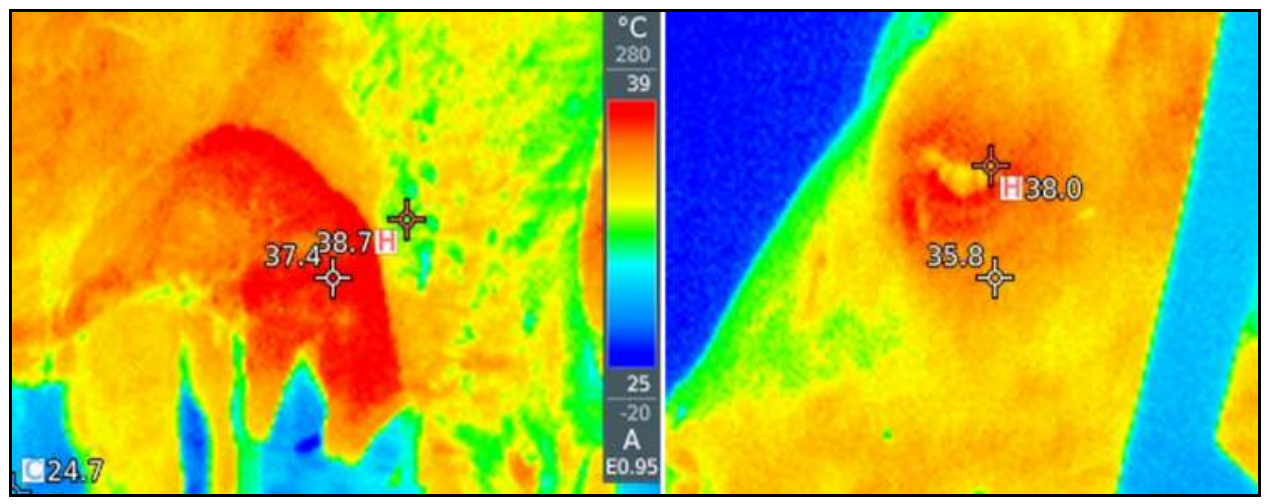

Graphic 1. Correlation and regression of THI and milk production and THI and skin temperature

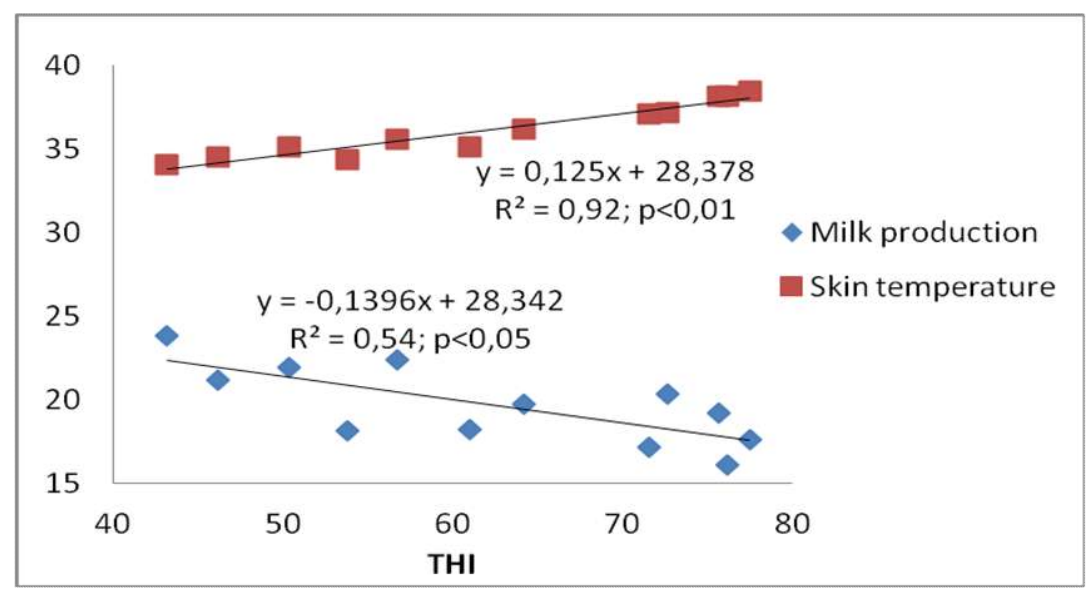


Graphic 2-13. Trend of THI changing values from 2005. To 2016. for each month. Significant positive linear trend of increasing THI value was determined in every month, except in January, October and November.

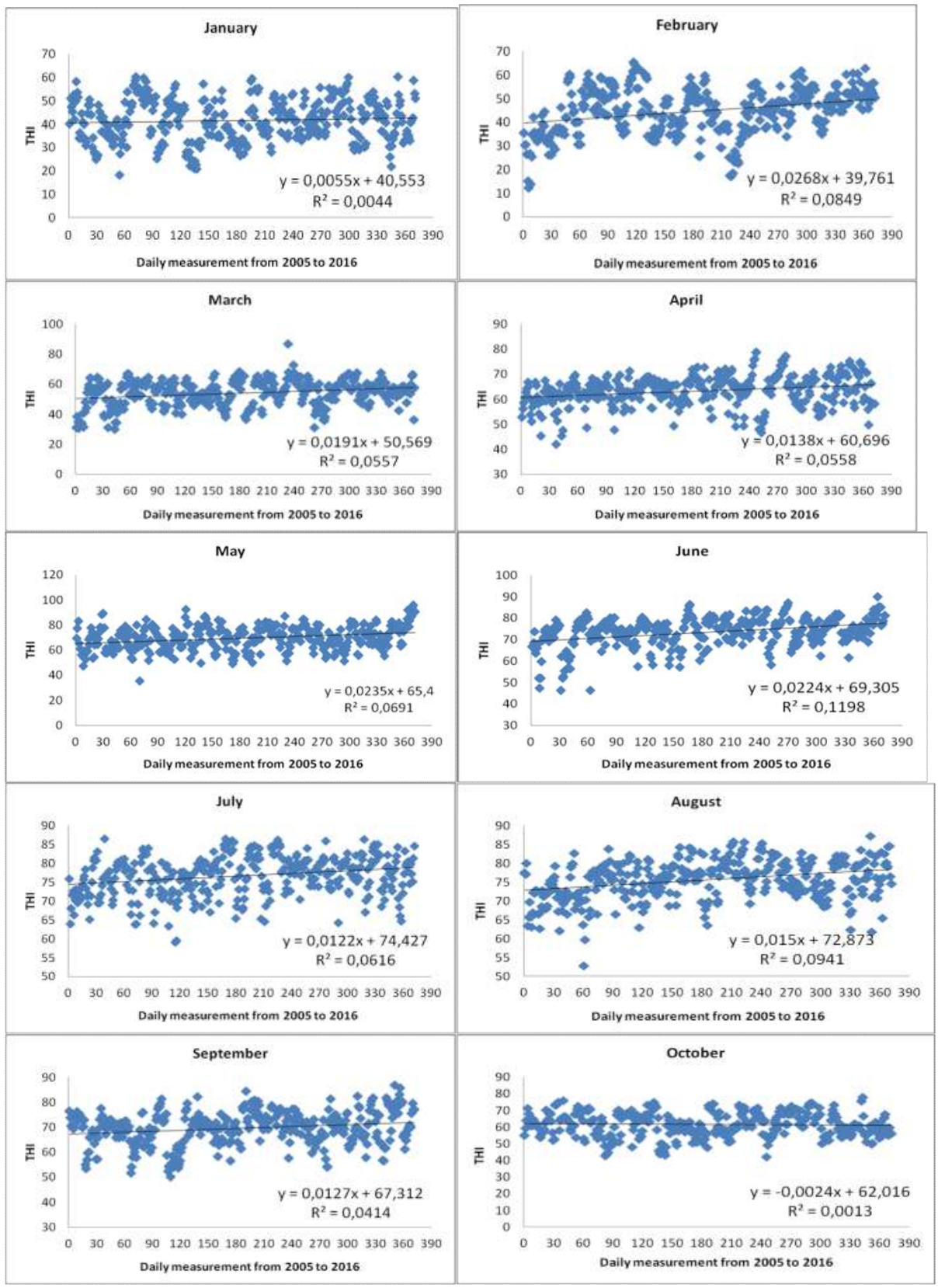



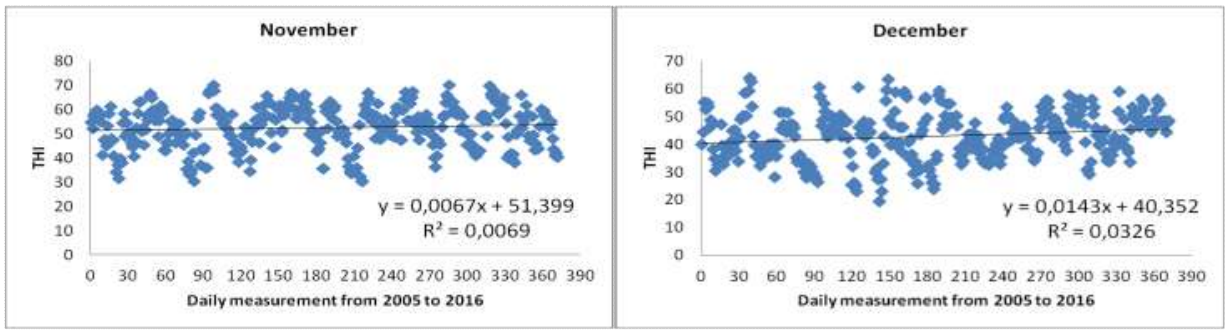

\section{Discussion}

Observing results conclusion would be that the maximum THI value is above the thermo neutral comfort. Climate changes cause an annual increase in maximum THI values for 0.19 units in June, 0.13 units in July and 0.44 units in August. The hottest years were 2007 in which June had 20 days that had THI $>74$ and 2012 with 22 hot days. Our results are consisted with Beniston (2004) and Black et al. (2004). They founded that most days with THI $>70$ occured during the summer (June-July-August). The heat waves in summer of 2003 and 2006 were extreme and over the last few decades, global average temeperatures have been rising (Solomon et al., 2007). Beniston (2003) has predicted that the heat wave would start two weeks earlier (than nowdays) and lasts two weeks longer than nowdays.

The main consequences of heat stress in cows are reduced intake of dry matter, increased body temperature, reduced milk production, mastitis and increased number of somatic cells in milk, silent or completely absent estrus, reduced conception, accelerated respiration in order to lose heat, subacute ruminal acidosis (Cincović, 2016). In England as a cosenqence hetawve during the 2006 milk production was reduced for $30 \%$ and future prediction for number of hot days could increase for 1-2 per year to over 20 per year, with correspondingly more (Dunn et al., 2014).

West et al. (2003) noticed that the reduction in milk yield may be as high as $0.9 \mathrm{~kg}$ of milk per cow every day for each degree that THI is increased. Ravagnolo et al. (2000a) found reduction of $0.2 \mathrm{~kg} /$ day. Bernabucci et al. (2010) noticed that THI values that range from 68 to 71, can cause reduction in milk production from $0.283 \mathrm{~kg} / \mathrm{h}$ or $-1.1 \mathrm{~kg} / \mathrm{cow} /$ days. In condition of mild to moderate stress, milk reduction is $0.303 \mathrm{~kg} / \mathrm{h}$ or $-2.7 \mathrm{~kg} / \mathrm{cow} / \mathrm{day}$. In moderate to severe heat stress, reduction of milk production is $0.322 \mathrm{~kg} / \mathrm{h}$ or $-3.9 \mathrm{~kg} / \mathrm{cow} /$ day. Daily decrease in milk production is in relation with duration of exposition to heat stress. Collier et al. (2011) founded that milk production was reduced when THI value is 68 . Milk losses at this THI value are $2.2 \mathrm{~kg} / \mathrm{day}$. Another study reported milk yield decreases by $0.2 \mathrm{~kg}$ per day when THI value is 72 (Ravagnolo et al., 2000b). 
Also, if a high THI period is prolonged in weather trend it can cause multiple problems. For example: drought can be associated with the hot weather and cause reduction of pasture quality. Besides that, animals are more succeptible to heatstress (Bryant et al., 2007). It is important to notice that sensitivity of cattle to heat stress increases with increased milk production. If milk production increases from 35 to $45 \mathrm{~kg}$ /day, sensitivity to heat stress is increases by $5 \%$.

When it comes to adaptation of cows to heat stress, biological features of animals have important role in this. Also lactation period can be related to sensitivity on heat stress, and cows that are in second part of lactation are more susceptible (Cincović et al., 2010). The next important factor is duration of the exposure to heat stress. Cows exposed to ambient temperature of $27^{\circ} \mathrm{C}$ for 40 or 80 days have significantly less production of milk than cows that are exposed to the same temperature for 20 days. The decline in milk production is stronger if the body temperature of cow exceeds $39^{\circ} \mathrm{C}$ for more than 16 hours per day (Rhoads et al., 2009).

Holstein-Friesian cows are more susceptible compared to Swiss gray or Simmental cows. These conclusions are based on the decline in milk production at the Holstein-Friesian cows that can be noticed when the ambient temperature is above $21^{\circ} \mathrm{C}$. For other races this temperature exceeds $24^{\circ} \mathrm{C}$. The influence of the skin color coating on the sensitivity of dairy cows to heat stress is significant. Animals with a darker skin cover dehydrate more quickly and their body temperature falls faster. The surface of the body is also significant when it comes to susceptability to heat stress. Smaller animals, those with lower body surface area, are better in tolerateing high external temperatures. This phenomenon can be explained by the fact that living beings are born with a final number of sweaty glands in the skin, so that rise in body surface leads to a relative decrease in the number of sweat glands per unit of skin area.

In one paper, the authors found that there are the following technological, biological and environmental factors that influence the temperature values that will be shown on the thermogram (Montanholi et al., 2008): there is a high repeatability of the thermogram values if they are made at a distance of 10 seconds, the measured temperature decreases the distance between the camera and the cow is larger, the results are consistent even when recording more people, the wind and debris (various residues) on the skin reduce the surface temperature of the body, exposure to the body by direct sunlight increases the surface of the body temperature or in regularities return to the initial level after a few minutes spent in the shade, the physical activity of the animal increases the body temperature, sedative and anti-sedative effects affect the surface temperature of the body, and the fetal imprint on the surface of the gravid calf gives higher temperatures in the thermogram. The results of the measurement depend on the anatomical location where the measurement is performed, and the largest correlation is shown between the temperatures measured in the area of the ears, the tail and the vulva. The surface of the body significantly correlates with 
the body temperature of the cows measured in tropical conditions (Martello et al., 2010).

When it comes to genetic affiliation, Bos indicus type of cattle is more susceptible to heat stress than Bos taurus cattle. The difference lies in the fact that Bos indicus cattle have a higher rate of basal metabolism (Ravagnolo $\mathrm{O}$ et al., 2000a). Another reason may be the difference in the density of the so-called arterial-venous anastomoses that are numerous in Bos indicus type. These structures have less resistance to blood flow than the capillary net, thus they facilitate flow of the blood to the skin during heat stress (Hansen. 2004). Bos Indicus type of cattle has a higher density of sweat glands, which are larger in size and are located closer to the surface of the skin. Degree of evaporation is higher in this type of cattle, and also sweating increases as the body temperature and ambient temperature rise. For these reasons they are less sensitive to heat stress. (Beatty et al.,2006) Cellular adaptation to high temperatures is also better in bos indicus cattle. The finding that there are genetic differences in cellular resistance to elevated temperature in cattle is the first example in endotherms of genetic adaptations in cellular resistance to elevated temperature. It is possible that the same gene or genes conferring cellular thermo tolerance are present because of the contribution of B. indicus genotypes to New World cattle breeds (Magee et al., 2002).

\section{Conclusion}

Biological adaptation of cows to high ambient temperatures is decreasing in milk production and increasing of body skin temperature. THI is very significant indicator of cows in heat stress. Mean maximal THI value from 20052016 showed trend of increasing in every month except January, October and November. Founded results go hand in hand with stories about global warming and climate changes that affect biological adaptation of cows.

\section{Acknowledgement}

This experiment is result of project, Examining high ambient temperature influence on zoohigienic farm parameters and metabolic adaptation of cows towards achieving sustainable milk production in different climates" financed by Provincial Secretariat for high education and science-research work AP Vojvodina. 


\section{References}

Beatty D., Barnes A., Taylor E., Pethick D., McCarthy M., Maloney S. (2006): Physiological responses of and cattle to prolonged, continuous heat and humidity. Journal of Animal Science, 84 (4), 972-985.

Beniston M. (2003): Climatic change in mountain regions: a review of possible impacts. Climatic change, 59 (1): 5-31.

Beniston M. (2004): The 2003 heat wave in Europe: a shape of things to come? An analysis based on Swiss climatological data and model simulations Geophys. Res. Lett. 31 L02202

Bernabucci U., Lacetera N., Baumgard L., Rhoads P., Ronchi B., Nardone A. (2010): Metabolic and hormonal acclimation to heat stress in domesticated ruminants. Animal, 4 (7): 1167-1183.

Black E., Blackburn M., Harrison G., Hoskins B., Methven J. (2004): Factors contributing to the summer 2003 European heatwave Weather, 59: 217-23

Bohmanova J., Misztal I., Cole J. (2007): Temperature-humidity indices as indicators of milk production losses due to heat stress. Journal of Dairy Science, 90 (4): 1947-1956.

Bryant J., Lopez-Villalobos N., Pryce J., Holmes E., Johnson C., Garrick D. (2007): Environmental sensitivity in New Zealand dairy cattle. Journal of Dairy Science, 90 (3), 1538-1547

Cincović M., Belić B., Toholj B., Radović I., Vidović B. (2010): The influence of $\mathrm{TH}$ values at different periods of lactataion on milk quality and characteristic of lactation curve. Journal of Agricultural Science, 55, 3: 235-241.

Cincović M. (2016): Metabolički stres krava. Univerzitet u Novom Sadu, Poljoprivredni fakultet Novi Sad: $182-206$.

Collier R., Zimbelman R., Rhoads R., Rhoads M., Baumgard L. (2011): A re-evaluation of the impact of temperature humidity index (THI) and black globe humidity index (BGHI) on milk production in high producing dairy cows. In Western Dairy Management Conf. Reno, NV. USA (pp. 113-125).

Dunn R., Willett K., Thorne P., Woolley E., Durre I., Dai A., Vose, R. (2012): HadISD: a quality-controlled global synoptic report database for selected variables at long-term stations from 1973-2011. Arhiv $1210.7191 \mathrm{v}$ (1).

Dunn R., Mead N., Willett K., Parker D. (2014): Analysis of heat stress in UK dairy cattle and impact on milk yields. Environmental research letters, 9(6), 1-11

Gaughan J., Mader T., Holt S., Lisle A. (2008): A new heat load index for feedlot cattle. Journal of Animal Science, 86 (10): 226-234

Hahn M., Riederer A., Foster S. (2009): The Livelihood Vulnerability Index: A pragmatic approach to assessing risks from climate variability and change. A case study in Mozambique. Global Environmental Change, 19 (1): 74-88.

Hansen P. (2004): Physiological and cellular adaptations of zebu cattle to thermal stress. Animal reproduction science, 82: 349-360.

Mader T., Davis M., Brown-Brandl T. (2006): Environmental factors influencing heat stress in feedlot cattle. Journal of Animal Science, 84 (3): 712-719. 
Magee D., Meghen C., Harrison S., Troy C., Cymbron T., Gaillard C., Bradley D. (2002): A partial African ancestry for the Creole cattle populations of the Caribbean. Journal of Heredity, 93 (6): 429-432.

Martello L.S., Savastano H. Jr., Silva S.L., Balieiro J.C. (2010): Alternative body sites for heat stress measurement in milking cows under tropical conditions and their relationship to the thermal discomfort of the animals. Intnational Journal of Biometeorology;54 (6): 647-52.

Montanholi Y.R., Odongo N.E., Swanson K.C., Schenkel F.S., McBride B.W., Miller S.P. (2008): Application of infrared thermography as an indicator of heat and methane production and its use in the study of skin temperature in response to physiological events in dairy cattle (Bos taurus). Journal of Biometeorology, 33:468-75.

Ravagnolo O, Misztal I., Hoogenboom G. (2000a): Genetic component of heat stress in dairy cattle, development of heat index function. Journal of Dairy Science, 83: 2120-5

Ravagnolo O., Misztal I. (2000b): Genetic component of heat stress in dairy cattle, parameter estimation. Journal of Dairy Science, 83: 2126-30

Rhoads M., Rhoads R., VanBaale M., Collier RJ., Sanders S., Weber W., Crooker B., Baumgard L. (2009): Effects of heat stress and plane of nutrition on lactating Holstein cows - Production, metabolism, and aspects of circulating somatotropin. Journal of Dairy Science, 92: 1986-1997.

RHMZS-Republički hidrometeorološki zavod Srbije http://www.hidmet.gov.rs/ (27.09.2017.).

RZS-Republički zavod za statistiku http://webrzs.stat.gov.rs/WebSite/Public/Page View.aspx?pKey=138\# (27.09.2017.)

Solomon S., D Qin., Manning Z., Chen M., Marquis K., Averyt M., Miller H. (2007): Contribution of Working Group I to the Fourth Assessment Report of the Intergovernmental Panel on Climate Changeed, Cambridge University Press, Cambridge, United Kingdom and New York, NY, USA.

West J . (2003): Effects of heat-stress on production in dairy cattle. Journal of Dairy Science, 86: 2131-2144. 


\title{
TERMALNI KOMFOR KRAVA I INDEKS TEMPERATURE I VLAŽNOSTI U PERIODU 2005-2016. NA TERITORIJI VOJVODINE (SRBIJA)
}

\author{
Marko R. Cincović ${ }^{1}$, Mira Majkić ${ }^{1}$, Branislava Belić ${ }^{1}$, Nada Plavša ${ }^{1}$, Ivana \\ Lakić $^{1}$, Miodrag Radinović ${ }^{1}$ \\ ${ }^{1}$ Univerzitet u Novom Sadu, Poljoprivredni fakultet, Departman za veterinarsku \\ medicinu, Laboratorija za patološku fiziologiju, Novi Sad, Srbija
}

\section{Rezime}

Cilj ovog rada je da se utvrdi vrednost indeksa temperature i vlažnosti vazduha (THI indeks, eng.temperature humidiry index) u periodu 2005- 2016 u regiji Vojvodine (Srbija) i njena korelacija sa proizvodnjom mleka i temperaturom površine tela kao znacima termalnog komfora. Indeks temperature i vlažnosti određen je pomoću sledeće formule $\mathrm{THI}=(1,8 \times$ Temperatura $)-(1$ Vlažnost $) \times($ Temperatura-14,3)+32. Podaci o temperaturi i vlažnosti dobijeni su iz zvaničnih izveštaja Hidrometeorološkog zavoda Srbije. Izračunate su prosečne mesečne vrednosti THI za svaku godinu od 2005-2016 za mesece i za merna mesta Vršac, Zrenjanin, Kikinda, Palić, Sombor, Rimski Šančevi i Sremska Mitrovica. U obzir su uzete temperature i vlažnosti izmerene u 14 časova, pa se u ovom ispitivanju radi o maksimalnim prosečnim vrednostima THI indeksa. Prikazan je trend vrednosti THI za svaki dan u okviru određenog meseca u godinama 2005-2016. Ispitana je prosečna proizvodnja konzumnog mleka u republici Srbiji za 2016.godinu. Ova godina je izabrana jer je poslednja ispitivana godina i odražava kumulativni efekat delovanja toplotnog stresa kod krava. Podaci su dobijeni iz zavoda za statistiku R.Srbije. Pomoću termovizijske kamere merena je kroz nekoliko ogleda temperatura kože vimena i temperature kože u regiji oka. Rezultati pokazuju da je vrednost THI bila u rasponu od 40,3 u januaru do 77,5 u julu mesecu. Prosečna maksimalna vrednost THI u periodu od 2005-2016 ukazuje na postojanje toplotnog stresa za mesece maj,jun,jul i avgust. Proizvodnja konzumnog mleka u 2016.godini bila je najviša u januaru, da bi potom opadala. Najniža proizvodnja mleka zabeležena je u avgustu, a potom proizvodnja lagano raste do decembra. Temperatura površine tela krava bila je u rasponu od 34,1 do $38,5^{\circ} \mathrm{C}$. Najviša temperature površine tela izmerena je u avgustu, a najniža u zimskom periodu. Nađena je značajna negativna korelacija desetogodišnjeg proseka THI i proizvodnje mleka, odnosno pozitivna korelacija THI i temperature površine tela. U periodu od 2005 do 2016 godine nađen je pozitivan linearni trend vrednosti THI izmerene u najtoplojem delu dana. U svakom mesecu postoji staistički značajan pozitivan linearan trend porasta vrednosti THI, osim u januaru, oktobru i novembru. Ekstremo topla leta u Srbiji 
nastaju svake pete godine, kada su krave posebno pogođene. Navedeni podaci govore u prilog globalnom zagrevanju i klimatskim promenama koje utiču na biološku adaptaciju krava.

Ključne reči: THI, toplotni stres, krave, trend. 